\title{
Edible insects contributing to food security?
}

\author{
Arnold van Huis ${ }^{*}$
}

\begin{abstract}
Because of growing demand for meat and declining availability of agricultural land, there is an urgent need to find alternative protein sources. Edible insects can be produced with less environmental impact than livestock. Insect meal can replace scarce fishmeal as feed ingredient, in particular in the fast growing aquaculture industry. Edible insects can alleviate waste disposal problems by growing them on organic by-products. About 2000 insect species are eaten worldwide, mostly in tropical countries. They have adequate protein quantity and quality and high content of unsaturated fatty acids and minerals like iron and zinc. Promotion of insects as food and feed will require the insects to be farmed. In tropical countries this is done small-scale, but in particular for use of insects as feed, production is needed in large automated industrial facilities. Food safety problems relate to contamination with pathogens, requiring hygienic farming. Proper labelling may be required for people allergic to seafood and house dust mites as cross reactivity may occur. Western consumers are hard to convince to eat insects, even when aware of environmental, nutritional and food safety benefits and their excellent taste. Emotional and psychological impediments to acceptance have to be addressed. The way forward of edible insects to become a new sector in agriculture and the food and feed industry is discussed. In particular, legislation lags behind developments and needs to be addressed urgently.
\end{abstract}

Keywords: Entomophagy, Insects as food and feed, Alternative protein sources, Mini-livestock, Nutrition, Bioconversion

\section{Background}

The Committee on World Food Security [1] stated that food security exists when all people, at all times, have physical, social and economic access to sufficient, safe and nutritious food to meet their dietary needs and food preferences for an active and healthy life. According to the committee the four pillars of food security are availability, access, utilization and stability; while the nutritional dimension is considered integral to the concept of food security. However, the sustainability (not compromising future generations' ability to meet their own needs) of future food security is increasingly considered. This has been captured in the term 'sustainable diets' [2]. Food production has a considerable environmental impact and future food systems need to take this into account [3]. In particular the production of

*Correspondence: arnold.vanhuis@wur.nl

Laboratory of Entomology, Wageningen University, Droevendaalsesteeg 1, 6708 PB Wageningen, The Netherlands meat, especially ruminant meat $[4,5]$, is more and more debated in view of environmental [6], societal [7] or food safety and animal welfare concerns $[8,9]$.

Meat demand is expected to increase globally by $76 \%$ from 2005/2007 to 2050 [10]. This increased demand in this time period is mainly from developing countries (113\%), less from developed countries (27\%). Some regions in the world show an increase of more than $150 \%$ from 2010 to 2050: the Middle East and North Africa $187 \%$, Sub-Saharan Africa $202 \%$ and South Asia $272 \%$ [11]. Globally, over a third of total world cereal production is used as livestock feed each year [12], which would be able to feed at least three billion humans [13]. Livestock is the world's largest user of agricultural land (68\%): in 2012 some 3360 million ha were under meadows and permanent pasture-more than twice the area under arable and permanent crops (FAOSTAT, consulted August 2015).

The impact of the livestock sector on the environment is considerable: deforestation, soil erosion;

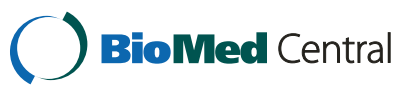

(c) 2015 van Huis. This article is distributed under the terms of the Creative Commons Attribution 4.0 International License (http:// creativecommons.org/licenses/by/4.0/), which permits unrestricted use, distribution, and reproduction in any medium, provided you give appropriate credit to the original author(s) and the source, provide a link to the Creative Commons license, and indicate if changes were made. The Creative Commons Public Domain Dedication waiver (http://creativecommons.org/publicdomain/ zero/1.0/) applies to the data made available in this article, unless otherwise stated. 
desertification, loss of plant biodiversity, public health hazards, and water pollution [6]. Besides, livestock production is responsible for more than $14 \%$ of all greenhouse gas emissions [14] and $59-71 \%$ of the global agricultural ammonia emissions [15]. Increased livestock productivity and technical mitigation strategies have been proposed such as the use of better quality feed and feed balancing to lower enteric and manure emissions, improved breeding and animal health, manure management practices, and improvements in energy use efficiency along supply chains $[13,14,16,17]$. Although by implementation of those measures $\mathrm{CO}_{2}$ equivalents may be cut by $60 \%$ by the year 2070, dietary changes have been considered crucial in order to meet the $2{ }^{\circ} \mathrm{C}$ temperature target set by the UNFCCC $[18,19]$. The global trend is that meat demand increases with income and urbanization. However without dietary changes, global agricultural greenhouse gas emissions from food production are estimated to increase by $80 \%$ in 2050 [5].

A dietary change would be to use alternative protein sources such as microalgae [20], seaweed, duckweed, and rapeseed [21], cultured meat [22] and insects [23, 24]. Insect can be considered as human food or as feed for pets, livestock and in aquaculture. Insect production seems to be more sustainable than livestock production for a number of reasons: lower greenhouse gas and ammonia emissions [25], less land area needed [26], more efficient feed conversion [23], and potential to be grown on organic by-products of which 1.3 billion tons is produced globally per annum [27] and the latter valued at US\$ 750 billion [28]. It seems that producing insects as mini-livestock requires less water than producing conventional livestock because the cold blooded insects have a high feed conversion efficiency. This enables them to derive most moisture from food and some insects can be grown on organic by-products reducing the water footprint of the feed [29]. However, this needs confirmation through a life cycle analysis.

Insects as food for humans and as feed for pets, livestock and fish will be discussed as well as their nutritional value. This review explores whether it is timely and appropriate to start considering insects as a sustainable and viable food and feed resource that can contribute to food security. Nutrition, farming, processing, marketing, food safety, legislation, consumer attitudes and the way forward will be reviewed and discussed.

\section{Insects as food}

In tropical countries most insect species are collected from nature. An inventory of the edible insect species eaten from all over the world, incorporating only scientific names and not vernacular names, yielded more than 2000 species [30]. Some countries stand out in the number of insect species eaten. This, however, is mostly related to the amount of research done. For example, Ramos-Elorduy wrote an impressive numbers of articles on entomophagy (the eating of insects) in Mexico (e.g. [31]), and Belgian scientists recorded more than 60 edible caterpillars from the Democratic Republic of Congo, a former Belgian colony [32]. This also means that many edible insect species have not yet been identified, requiring further exploration [33].

The reason that insects are predominantly eaten in tropical countries is that they are larger and often occur clumped, which facilitates harvesting. Also, in the absence of a winter season, insect species can be found during the whole year. Most insect species occur seasonally as they depend on the availability of their host plant; others may occur throughout the year such as most aquatic insects. Representatives from almost all insect groups are eaten such as beetles $(31 \%)$, caterpillars (18\%), wasps, bees and ants (15\%), crickets, grasshoppers and locusts (13\%), true bugs (11\%), and termites, dragonflies, flies and others (12\%) [30]. Other arthropod groups such as spiders and scorpions are also eaten. Some species are semi-domesticated which means that certain measures are taken to make the harvesting more predictable [34]. For example, palm trees may be cut deliberately, in order to trigger palm weevils of the genus Rhynchophorus (Coleoptera: Curculionidae) to oviposit on the trunk. After a certain time the larvae are then harvested. These larvae are considered an absolute delicacy in many parts of the world. In Central Africa the collection of arboreal, foliage consuming caterpillars is facilitated by manipulating host tree distribution and abundance, shifting cultivation, fire regimes, host tree preservation, and manually introducing caterpillars to a designated area.

There is little information about how often and how much insects are consumed in the tropics (see for some examples chapter 2 of Van Huis et al. [24]). This is mainly because national agricultural statistics do not include insects as food or feed. The large majority of insects in developing countries are gathered from wild populations in nature, in farmlands or in forests. Those are self-consumed and the access sold for cash at village markets or to middlemen and wholesalers at the farm gate. Edible insects offer a cheap and efficient opportunity to improve livelihoods and the quality of traditional diets among vulnerable people.

Recently in western countries the interest of using insects as food has gained momentum. A number of companies have started to produce insects for human consumption. For example in the United States, these are often crickets which are marketed in processed products such as protein bars. In some countries they 
are already sold in supermarkets. This will be dealt with in the chapter about processing, marketing and consumer attitudes.

\section{Insects as feed}

Insects as feed ingredient has been reviewed in general [35, 36], for fish [37], and specifically for West Africa [38]. Appropriate palatability of insect meal for poultry, pigs, fish species and ruminants was demonstrated and insects could replace $25-100 \%$ of soymeal or fishmeal depending on the animal species [36]. For large scale production the most promising species are the Black soldier fly Hermetia illucens (Diptera: Stratiomyidae) and the Domestic house fly Musca domestica (Diptera: Muscidae). However, a number of other species are also considered such as mealworms, termites, grasshoppers, crickets, and caterpillars (such as the silkworm). The use of the Black soldier fly as feedstuff has been investigated for chickens, pigs, channel catfish, African catfish, blue tilapia, turbot, and rainbow trout $[39,40]$. Fly larvae can be used to recycle agricultural by-products like coffee pulp, palm kernel meal, manure, and organic waste materials like fish offal, market waste, municipal organic waste, dewatered faecal sludge, organic leachates and distiller's dried grains with solubles (DDGS) [41, 42]. Persistent pollutants such as heavy metals often occur in organic waste streams. In an experiment, cadmium accumulated in the Black soldier fly prepupae limiting their potential to be used in animal feed, while in the case of lead and zinc, this proved to be less critical [43]. The maggots of the Domesticated housefly can also be used as a protein source to feed poultry, fish and crustaceans. The larvae can be reared on waste substrates such as pig or poultry manure, mixtures of cattle blood with wheat bran or rumen contents [36]. The advantages of using the Domesticated housefly is that they have a very short life cyle (6-10 days). A life cycle analysis conducted for the Domesticated housefly indicated that by producing insect meal compared to fishmeal and soymeal, land use decreased, but energy use increased [44]. In this specific study it was indicated that energy use may be decreased and that insect meal has potential to reduce the environmental impact of the livestock sector.

Use of insects in aquaculture has recently received quite some interest. This has to do with the diminishing availability of fishmeal as a major dietary protein source in compounded feed for many important farmed species. Fishmeal is made from pelagic fish harvested from international waters, and international fisheries are being over-exploited and current practices are not sustainable. The demand for fishmeal has increased because the farming of fish and shellfish has been the fastest growing food producing sector in the last few decades (it is still growing by $6 \%$ a year) and has become an important industry in many countries. Farmed food fish in 2012 was $42 \%$ of all fish produced in the world both by capture fisheries and aquaculture (in 1990 it was only $13 \%$ ). Therefore, the production of fishmeal and fish oil has diminished from 30 million tons (live weight) in 1994 to 16 million tons in 2012 [45].

This shortage has prompted a search to identify alternative protein sources [46], including use of insects. In particular in aquaculture, insect meal is an interesting alternative to soymeal as feedstuffs of vegetable origin have a number of disadvantages, such as imbalances between essential and nonessential amino acids, antinutritional factors, low palatability and a high proportion of fibre and non-starch polysaccharides [47]. Since 2013, the European Union Regulation (EU) 56/2013 allows the use of insects in feed for fish in aquaculture. In Norway, studies have demonstrated that insect meal is a good source of protein for farmed salmon [48]. The Research Council of Norway has recently allocated more than one million euro to investigate the potential of using insects as safe and healthy fish feed ingredient. ${ }^{1}$

\section{Nutrition}

It is difficult to generalize the nutritional composition, but Rumpold, Schlüter [49] consulted more than 50 literature references. Data from 236 of the more than 2000 edible insect species show that, despite the large variation, they provide satisfactory energy and protein, meet amino acid requirements for humans, are high in monounsaturated fatty acids and polyunsaturated fatty acids, and rich in several minerals and vitamins [49]. Of particular interest are the high iron and zinc content in comparison to conventional meat. Therefore, entomophagy has been proposed to combat the deficiencies of these minerals in developing countries [50], in particular in view of the fact that the percentage of the world population at risk for these deficiencies is more than $17 \%$ for zinc [51] and $25 \%$ for iron [52].

Species considered for consumption in the western world, like mealworms and crickets, have a protein content ranging from 19 to $22 \%$. This is comparable to conventional meat products in terms of protein quantification [53]. The essential amino acid levels in the insect species investigated by these authors were comparable with soybean proteins, but lower than for casein. For future food applications it is promising that gels could be formed and soluble fractions obtained by a simple aqueous extraction procedure.

\footnotetext{
${ }^{1} \mathrm{http}: / /$ nifes.no/en/counting-insects-future-fish-feeds/ (accessed 15 Oct 2015).
} 


\section{Farming}

As mentioned above, in tropical countries most insect species are collected from nature. However, if insects are to become an important resource, they need to be farmed as mini-livestock. Besides, in nature edible insect resources are already threatened due to overexploitation and habitat degradation [54] or pesticide use [55]. For example, the collection and marketing of the Mopane caterpillar Imbrasia belina (Lepidoptera: Saturniidae) compromises the sustainable use of forestry resources. For this reason a restriction of the harvesting period has been proposed [56].

A country where insect farming plays an important role is Thailand, where 20,000 farms produce around 7500 tonnes per year [57] with activities expanding into Laos [58] A number of international projects are now operational to promote insect rearing for human consumption in Africa, concentrating mainly on crickets. It has been tried to farm commercially important insect species such as the Mopane caterpillar. However, pathogen spreading through a captive population remains a problem and economically it is not yet viable [59].

In the western world insect rearing companies produce a number of insect species as pet food. In the Netherlands some companies have set up special production lines for human consumption (in particular mealworms, crickets and locusts). However, when insects are considered as feed, feedstock companies require large, reliable and continuous supplies of high and stable quality, which can only be achieved in industrial automated rearing facilities. Very recently, in different parts of the world such activities have been initiated, concentrating mainly on the Black soldier fly and the Domestic house fly. Insects as feed have the potential of becoming a very large market considering that global feed tonnage in 2014 measured at 980 million metric tons (value $\$ 460$ billion), destined for poultry (45\%), pigs (27\%), ruminants (20\%), aquaculture $(4 \%)$, pets $(2 \%)$, horses $(1 \%)$ and others (1\%) [60].

Increased production of insects on a large scale for food and feed will lead to many novel challenges, including problems with diseases. One example is the Acheta domesticus densovirus (AdDNV) frequently decimating commercial rearing of the house cricket, A. domesticus (Orthoptera: Gryllidae) in Europe and parts of North America [61]. Early detection, development of sanitizing methods, and shifting to other cricket species have been proposed as solutions [62].

\section{Processing and marketing}

The trade of the Mopane caterpillar in southern Africa is big business. Already in 1994 Styles in [63] estimated that an annual population of 9500 million mopane caterpillars in South Africa's 20,000 $\mathrm{km}^{2}$ of mopane veld was valued at more than US\$ 80 million of which approximately $40 \%$ goes to producers who are primarily poor rural women. In Kenya, complementary foods based on edible termites were developed and evaluated to combat child malnutrition. Results indicated that it can be processed in affordable and safe foods with adequate nutrient density [64]. In Kenya, termites and lake flies were baked, boiled and cooked to increase shelf life and processed into conventional consumer products such as crackers, muffins, sausages and meat loaf to encourage entomophagy [65]. These are strategies to make the products which are collected from nature available over longer periods. Preserving edible insects and insect products can be done without the use of a refrigerator through techniques such as drying, acidifying, and lactic fermentation [66]. However, to better regulate and assure the supply of such insect products, insects should be farmed. Then freeze-drying (dehydration by sublimation of the frozen insect) is often practiced. This stops most of deterioration and microbiological reactions and gives the final product an excellent quality. That is how they are brought on the market in the Netherlands. When grinding the freezedried product, they can be processed into other insect products. In the Netherlands one supermarket chain with 500 outlets has processed the lesser mealworm, Alphitobius diaperinus (Coleoptera: Tenebrionidae) into burgers, nuggets and schnitzels. ${ }^{2}$

\section{Food safety and legislation}

Food safety issues have been addressed by a number of authors with immediate impact on legislative issues [21, $49,67,68]$. Possible hazards are contaminants, like heavy metals, mycotoxins, pesticide residues, and pathogens. The information available about the consumption of insects in tropical countries suggests that insects harvested for human consumption do not cause any significant health problems [69], but there is little information about insects that are farmed either for food or feed. In general, insect pathogens are specific for invertebrates and do not harm vertebrates [70].

At the time the legislation was made, nobody considered insects as either food or feed, and when in the legislation the word "animal" is used, insects are often automatically part of that legislation. A clear example is the EU Regulation 1099/2009 in which it is stated that animals have to be slaughtered in certified slaughterhouses in the presence of an Animal Welfare Officer; clearly this was not designed to apply to insects [68].

\footnotetext{
2 http://www.bbc.com/news/world-europe-29865959 (accessed 15 Oct 2015). 
Van der Spiegel et al. [21] discuss food safety issues and legislative issues relating to edible insects in the EU. Concerning insects as food, it has not been decided yet in the EU whether an insect product is considered a novel food (definition: not consumed "in a significant degree" in the EU before May 15, 1997). If so, the producer has to provide a Novel Food Dossier, among others, proving the product is safe for the consumer.

Concerning insects as feed the EU issued a regulation in 2013 allowing the use of non-ruminant proteins in feed for fish in aquaculture; a lifting of the ban on insect proteins in the feed of food-producing pigs and poultry is being considered [21], and a decision is expected in 2015.

Concerning allergies, people allergic to house dust mites and crustaceans may react to food containing insects, such as the Yellow mealworm Tenebrio molitor (Coleoptea: Tenebrionidae) [71]. Recent evidence suggests that insects and crustaceans (like shrimps), long considered widely separated branches of the arthropod family tree, actually are taxonomically closely related [72]. When proven allergenic, proper labelling of the insect product would be required.

\section{Consumer acceptance}

In tropical countries insects are used as an important protein source, while westerners are reluctant to use insects as food. Almost a hundred years ago, Bequaert [73] attributed the aversion of western people to include insects in their diet to 'prejudice', and cultural conditioning: "What we eat and what we do not eat is, after all, a matter of custom and fashion (rather) than anything else". DeFoliart [74] also considered the western attitude and bias against eating insects a severe handicap to introducing this sustainable food source. Yen [75] warned that 'westernization' of societies where insects are eaten would cause a movement away from entomophagy while western societies, being major consumers of livestock protein, would miss an opportunity to reduce their environmental footprint.

Others have stressed the need for development of strategies to overcome the psychological and cultural barriers to entomophagy and considered valuing insects as human food a challenging test case [76]. In Belgium and the Netherlands studies revealed that adoption of insects as a protein source was strongly influenced by motivations towards sustainable food consumption [77, 78]. However, consumers in Thailand, where insects are part of the local food culture, considered insects more in terms of their taste and familiarity than Dutch consumers. For example, Thai participants were strongly repulsed by mealworms, due to the association with larvae often seen in decaying matter [77]. This association was absent amongst Dutch participants who were more familiar with mealworms as food. To overcome the reluctance to eat insects the following strategies have been proposed: (1) To increase familiarity with the product by providing consumers with information about the insects as a sustainable alternative food source [79]. (2) To make edible insect available and provide knowledge about how to prepare them [76]. (3) To stress the systematic proximity in animal classification between insects and crustaceans [80]. (4) To increase frequencies of edible insect exposure and experimental tasting [76, 79]. (5) To develop appropriate products that not only lower the barriers to trying, but also taste good and are appealing to eat $[77,81]$. (6) To incorporate insects into familiar food items [82]. (7) To use role models such as the former secretary general of the United Nations Kofi Annan who was interviewed about edible insects [83]. (8) To target children for education in entomophagy [84].

\section{The way forward}

The interest in insects as food and feed is very recent and was partly triggered by the publication of the FAO report in 2013 [24], which has been downloaded more than 7 million times. A first conference on this topic "Insects to feed the world", was jointly organized by Wageningen University and the FAO in 2014 in the Netherlands. This conference attracted 450 participants from 45 countries. Research institutions, universities, private companies, international organizations, civil society, and governmental agencies in the agriculture, food, feed, and health sectors were represented [85].

Until recently the eating of insects was considered to be a peculiar habit of ethnic groups in the tropics. Before 2000, most references were found in ethno-biological literature. This is now changing as scientific literature on the topic increases. A Web of Science search (August 2015) using "edible insects" as topic yielded 10 results from 2000 to 2004, 18 from 2005 to 2009 and 65 from 2000 to 2014; the same search with Google Scholar yielded 265, 460 and 1.010 results, respectively.

Because of the cultural bias in the view of entomophagy as only an odd practice of "primitive man" in tropical countries $[33,86]$, international and donor organizations have paid scant attention to it. Therefore, we hardly know to which extent insects are eaten by people in the tropics, except for some cases of specific countries and insect species (see for examples Chapter 2 in Van Huis et al. [24]). There is a need for compilation of (inter)national statistical data on production and trade in insect products for food and feed.

It is difficult to present a generalized picture of the nutrient content of insects in the recorded 2000 species. Of interest in this context are: energy and protein content, amino acid profiles, mono-unsaturated and polyunsaturated fatty acid content, and micronutrients, in 
particular iron and zinc. As the nutrient composition of insects is dependent on feed, opportunities for regulation, enrichment, and addition of certain food ingredients should be investigated. The immunological effects of consuming the exoskeleton of insects should also be addressed in food and feed, as chitin is able to recruit and activate innate immune cells [87].

Harvesting edible insects from natural resources fosters livelihoods, as they can be self-consumed and/or marketed. To prevent overexploitation, research into sustainable harvesting, semi-domestication and farming is necessary. The harvesting of some insect pests, like edible grasshoppers in Mexico, can serve as a control method [88].

Veterinary science in insect farming is in its infancy. Very little is known about insect diseases which may emerge at large-scale rearing: biological and genetic characterisation, phylogeny, host range, transmission, persistence, epidemic potential and safety for animals including humans [70]. The transmission of diseases has proven to be problematic on a global scale in the conventional livestock sector. Prevention, detection, identification, and mitigation of microbial contaminants are crucial for a successful and safe insect production. Using insects to transform organic side streams including manure into high protein products is a very interesting option. However, the quality of the used waste and the produced insects need further empirical studies and monitoring. The potential risk for human health, if the insect-based food or feed is contaminated with harmful microorganisms, mycotoxins or heavy metals, is in urgent need of attention.

Legislative barriers in the western world currently hinder the advancement of the emerging sector of insects as food and feed. De-Magistris et al. [89] argue that the unfamiliarity with insects as food in the European Union may influence EU decision making as consumers are "conditioned" by cultural patterns and issues of neophobia when it comes to edible insects. This may result in a lower degree of openness for innovations. On the one hand the EU explores and fosters novel and sustainable source of food ingredients such as insects, but on the other hand hampers those innovations by enforcing a regulatory environment to protect consumers against risks from novel food products. Using as an example the case of whole insects (allowed) or processed edible insects (not allowed), de-Magistris et al. [89] conclude that there is a misalignment between the European Novel Food Regulation (EC) 258/97 (ENFR) policies and R\&D innovation measures.

Concerns have been expressed over the profitability of producing insects on a large scale because, it is labour intensive and feed costs are high [90]. Automation of production activities will be necessary to cheaply and reliably produce large quantities of high standard and safe insect products. The use of low-value organic by-products and waste streams is another way of reducing costs of the feedstock [91]. Producing fly larvae from organic waste on an industrial scale requires more technological knowledge of scaling-up the production capacity. Optimization of fly egg production is another bottleneck [42]. Worldwide a number of companies are engaging in this endeavour. One company is able to process 20 tonnes of fly larvae a day, which translates into seven tonnes of insect meal and three tonnes of insect oil [92]. Considering that large volumes of feed are required for pets, fish and livestock, and bearing in mind the continuous rising prices of the ingredients fishmeal and soymeal, the use of insect meal as an alternative protein source becomes an option of increasing interest. Optimization of desirable traits of an insect species by selecting certain strains or by using genetical improvement strategies needs more attention.

Product development of insects as food should take into account cultural and individual expectations about the species to be used as food and how they should be prepared. Stressing health and environmental benefits are insufficient to encourage consumption. The acceptability of insects as a sustainable food source also requires research in gastronomy (deliciousness).

To advance the new agricultural sector of insects as food and feed, multiple disciplinary approaches are required (multi-disciplinarity, inter-disciplinarity, and trans-disciplinarity) as complex problems have to be resolved which transcend traditional boundaries and require the collaboration of non-academic stakeholders.

\section{Conclusions}

The current livestock production is facing serious challenges: (1) Global land area is insufficient to satisfy the increasing demand for animal protein. (2) Targeted reduction of greenhouse gas emissions is not possible with mitigation strategies. Dietary changes are needed. Insects as mini-livestock offer many environmental benefits compared to conventional livestock, while nutritional quality is similar. The benefits are in terms of greenhouse gas emissions, land area needed, feed conversion efficiency and the potential to be grown on organic by-products. More than 2000 insect species are already eaten in tropical countries, most of them harvested from nature. Fishmeal as feed in aquaculture is becoming scarce, and fly larvae are a better alternative protein source than ingredients of vegetable origin. If insects are promoted as food and feed, they need to be farmed. As poultry, pigs and fish use more than $75 \%$ of the global feed produced, the potential of industries to produce insects as a new 
protein source is huge. Worldwide start-up companies are engaging in this. When grown on organic by-products, food safety issues need to be considered because of possible contaminants. The acceptance of insects as food gains momentum in western countries and a number of strategies to convince consumers are employed such as incorporating them into familiar products. A new agricultural sector is emerging, but it is still in a rudimentary stage. This article indicates how to take it further.

\section{Abbreviations}

AdDNV: Acheta domesticus densovirus; DDGS: distiller's dried grains with solubles; EU: European Union; FAO: Food and Agriculture Organization of the United Nations; UNFCCC: United Nations Framework Convention on Climate Change.

\section{Acknowledgements \\ Kees Eveleens provided helpful comments on the draft manuscript.}

\section{Competing interests}

The author declares that he has no competing interests.

Received: 12 May 2015 Accepted: 20 October 2015

Published online: 15 December 2015

\section{References}

1. CFS. 35th Session, Agenda Item III, Reform of the Committee on World Food Security (CFS). Final Version. Rome: FAO; 2009

2. Berry EM, Dernini S, Burlingame B, Meybeck A, Conforti P. Food security and sustainability: Can one exist without the other? Public Health Nutr. 2015; doi:10.1017/S136898001500021X.

3. Lang T, Barling D. Nutrition and sustainability: an emerging food policy discourse. Proc Nutr Soc. 2013;72(1):1-12.

4. Nijdam D, Rood T, Westhoek $H$. The price of protein: review of land use and carbon footprints from life cycle assessments of animal food products and their substitutes. Food Policy. 2012;37(6):760-70.

5. Tilman D, Clark M. Global diets link environmental sustainability and human health. Nature. 2014;515(7528):518-22.

6. Steinfeld H, Gerber P, Wassenaar T, Castel V, Rosales M, de Haan C, editors. Livestock's long shadow Environmental issues and options. Rome: Food and Agriculture Organization of the United Nations; 2006.

7. Weis T. The meat of the global food crisis. J Peasant Stud. 2013:40(1):65-85.

8. D'Silva J, Webster J. The meat crisis: developing more sustainable production and consumption. London: Earthscan; 2010.

9. Lymbery P. Farmageddon: the true cost of cheap meat. London: Bloomsbury Publishing; 2014.

10. Alexandratos N, Bruinsma J. World agriculture towards 2030/2050: The 2012 Revision. Global Perspective Studies Team ESA Working Paper No 12-03. Rome: Agricultural Development Economics Division of the Food and Agriculture Organization of the United Nations; 2012

11. Rosegrant MW, Tokgoz S, Bhandary P. The new normal? a tighter global agricultural supply and demand relation and its implications for food security. Am J Agric Econ. 2012;95(2):303-9.

12. FAO. World agriculture: towards 2015/2030. Summary report. Rome: Food and Agriculture Organization of the United Nations; 2002

13. Eisler MC, Lee MR, Tarlton JF, Martin GB, Beddington J, Dungait JA, et al. Agriculture: steps to sustainable livestock. Nature. 2014;507(7490):32-4

14. Gerber PJ, Steinfeld H, Henderson B, Mottet A, Opio C, Dijkman J, et al. Tackling climate change through livestock-a global assessment of emissions and mitigation opportunities. Rome: Food and Agriculture Organization of the United Nations; 2013.
15. Beusen AHW, Bouwman AF, Heuberger PSC, Van Drecht G, Van Der Hoek KW. Bottom-up uncertainty estimates of global ammonia emissions from global agricultural production systems. Atmos. Environ. 2008:42(24):6067-77.

16. Herrero M, Thornton PK. Livestock and global change: emerging issues for sustainable food systems. Proc Natl Acad Sci U S A 2013:110(52):20878-81.

17. Wirsenius S, Azar C, Berndes G. How much land is needed for global food production under scenarios of dietary changes and livestock productivity increases in 2030? Agric Syst. 2010;103(9):621-38

18. UNFCCC. Decision 1/CP.16: the Cancun agreements: outcome of the work of the ad hoc working group on long-term cooperative action under the United Nations Framework Convention on Climate Change (UNFCCC). Bonn: UNFCCC document FCCC/CP/2010/7/Add1; 2010.

19. Hedenus F, Wirsenius S, Johansson DA. The importance of reduced meat and dairy consumption for meeting stringent climate change targets. Clim Change. 2014;124:1-13.

20. Becker EW. Micro-algae as a source of protein. Biotechnol Adv. 2007;25(2):207-10.

21. Van der Spiegel M, Noordam MY, van der Fels-Klerx HJ. Safety of novel protein sources (insects, microalgae, seaweed, duckweed, and rapeseed) and legislative aspects for their application in food and feed production. Compr Rev Food Sci Food Saf. 2013;12(6):662-78.

22. Post MJ. Cultured meat from stem cells: challenges and prospects. Meat Sci. 2012;92(3):297-301.

23. Van Huis A. Potential of insects as food and feed in assuring food security. Annu Rev Entomol. 2013;58(1):563-83.

24. Van Huis A, Van Itterbeeck, Klunder H, Mertens E, Halloran A, Muir G et al. Edible insects: future prospects for food and feed security. FAO Forestry Paper 171. Rome: Food and Agriculture Organization of the United Nations; 2013. http://www.fao.org/docrep/018/i3253e/i3253e.pdf Accessed 1 Oct 2015

25. Oonincx DGAB, Van Itterbeeck J, Heetkamp MJW, Van den Brand H, Van Loon JJA, Van Huis A. An exploration on greenhouse gas and ammonia production by insect species suitable for animal or human consumption. PLoS ONE. 2010;5(12):e14445.

26. Oonincx DGAB, De Boer IJM. Environmental impact of the production of mealworms as a protein source for humans-a life cycle assessment. PLoS ONE. 2012;7(12):e51145

27. FAO. Global food losses and food waste-extent, causes and prevention. Rome: Food and Agriculture Organization of the United Nations; 2011

28. Economist. Food loss and its intersection with food security. Global food security index 2014: An annual measure of the state of global food security. A report from the Economist Intelligence Unit. London: The Economist; 2014. http://www.eiu.com/public/topical_report. aspx?campaignid=foodloss14 Accessed 1 Oct 2015.

29. Rumpold BA, Schlüter OK. Potential and challenges of insects as an innovative source for food and feed production. Innov Food Sci Emerg Technol. 2013:17:1-11.

30. Jongema Y. List of edible insect species of the world. Wageningen: Laboratory of Entomology, Wageningen University, The Netherlands; 2014. http://www.entwurnl/UK/Edible+insects/Worldwide+species+list/ Accessed 1 Oct 2015.

31. Ramos-Elorduy J, Morales JMP. Los insectos comestibles en el México antiguo (estudio etnoentomológico). Mexico: AGT Editor; 1989.

32. Malaisse F, Lognay G. Les chenilles comestibles d'Afrique Tropicale. In: Motte-Florac E, Thomas JMC, editors. Les insectes dans la tradition orale. Leuven: Peeters; 2003. p. 279-304.

33. Costa-Neto EM. Anthropo-entomophagy in Latin America: an overview of the importance of edible insects to local communities. J Insects Food Feed. 2015;1(1):17-23

34. Van Itterbeeck J, van Huis A. Environmental manipulation for edible insect procurement: a historical perspective. J Ethnobiol Ethnomed. 2012;8(3):1-19.

35. Anankware P, Fening KO, Osekre E, Obeng-Ofori. Insects as food and feed: a review. Int J Agric Res Rev. 2015;3(1):143-51.

36. Makkar HPS, Tran G, Heuzé V, Ankers P. State-of-the-art on use of insects as animal feed. Anim Feed Sci Tech. 2014;197:1-33.

37. Henry M, Gasco L, Piccolo G, Fountoulaki E. Review on the use of insects in the diet of farmed fish: past and future. Anim Feed Sci Tech. 2015;203:1-22. 
38. Kenis M, Koné N, Chrysostome CAAM, Devic E, Koko GKD, Clottey $V A$, et al. Insects used for animal feed in West Africa. Entomologia. 2014;2(218):107-14

39. Adeniyi OV, Folorunsho CY. Performance of Clarias gariepinus (Burchell, 1822) Fed dietary levels of Black soldier fly, Hermetia illucens (Linnaeus, 1758) prepupae meal as a protein supplement. Int J Fish Aquac 2015;5(3):89-93.

40. Tschirner M, Simon A. Influence of different growing substrates and processing on the nutrient composition of black soldier fly larvae destined for animal feed. J Insects Food Feed. 2015;1(3):1-12.

41. Webster CD, Rawles SD, Koch JF, Thompson KR, Kobayashi Y, Gannam AL, et al. Bio-Ag reutilization of distiller's dried grains with solubles (DDGS) as a substrate for black soldier fly larvae, Hermetia illucens, along with poultry by-product meal and soybean meal, as total replacement of fish meal in diets for Nile tilapia, Oreochromis niloticus. Aquacult Nutr. 2015;. doi:10.1111/anu.12316.

42. Čičková H, Newton GL, Lacy RC, Kozánek M. The use of fly larvae for organic waste treatment. Waste Manag. 2015;35:68-80.

43. Diener S, Zurbrügg C, Tockner K. Bioaccumulation of heavy metals in the black soldier fly, Hermetia illucens and effects on its life cycle. J Insects Food Feed. 2015;. doi:10.3920/JIFF2015.0030

44. Van Zanten HHE, Mollenhorst H, Oonincx DGAB, Bikker P, Meerburg BG, de Boer IJM. From environmental nuisance to environmental opportunity: housefly larvae convert waste to livestock feed. J Clean Prod. 2015;102:362-9.

45. FAO. The state of world fisheries and aquaculture. Rome: FAO Fisheries and Aquaculture Department, Food and Agriculture Organization of the United Nations; 2014.

46. Olsen RL, Hasan MR. A limited supply of fishmeal: impact on future increases in global aquaculture production. Trends Food Sci Tech. 2012;27(2):120-8

47. Sánchez-Muros M-J, Barroso FG, Manzano-Agugliaro F. Insect meal as renewable source of food for animal feeding: a review. J Clean Prod. 2014;65:16-27.

48. Lock ER, Arsiwalla T, Waagbø R. Insect larvae meal as an alternative source of nutrients in the diet of Atlantic salmon (Salmo salar) postsmolt. Aquac Nutr. 2015; doi:10.1111/anu.12343.

49. Rumpold BA, Schlüter OK. Nutritional composition and safety aspects of edible insects. Mol Nutr Food Res. 2013;57(5):802-23.

50. Christensen DL, Orech FO, Mungai MN, Larsen T, Friis H, Aagaard-Hansen J. Entomophagy among the Luos of Kenya: a potential mineral source? Int J Food Sci Nutr. 2006:57(3/4):198-203.

51. Gibson RS. Dietary-induced zinc deficiency in low income countries: challenges and solutions the avanelle kirksey lecture at Purdue university. Nutr Today. 2015;50(1):49-55.

52. McLean E, Cogswell M, Egli I, Wojdyla D, de Benoist B. Worldwide prevalence of anaemia, $\mathrm{WHO}$ vitamin and mineral nutrition information system, 1993-2005. Public Health Nutr. 2009;12(4):444-54.

53. Yi L, Lakemond CMM, Sagis LMC, Eisner-Schadler V, Van Huis A, Van Boekel MAJS. Extraction and characterization of protein fractions from five insect species. Food Chem. 2013:141(4):3341-8.

54. Ramos-Elorduy J. Threatened edible insects in Hidalgo, Mexico and some measures to preserve them. J Ethnobiol Ethnomed. 2006;2:51 doi:10.1186/1746-4269-2-51 (online journal)

55. Payne CLR. Wild harvesting declines as pesticides and imports rise: The collection and consumption of insects in contemporary rural Japan. J Insects Food Feed. 2015;1(1):57-65.

56. Akpalu W, Muchapondwa E, Zikhali P. Can the restrictive harvest period policy conserve mopane worms in southern Africa? A bioeconomic modelling approach. Environ Dev Econ. 2009;14(5):587-600.

57. Hanboonsong Y, Jamjanya TT, Durst P PB. Six-legged livestock: edible insect farming, collection and marketing in Thailand. Bangkok: Regional Office for Asia and the Pacific of the Food and Agriculture Organization of the United Nations; 2013.

58. Hanboonsong Y, Durst PB. Edible insects in Lao PDR: building on tradition to enhance food security. Rap Publication 2014/12. Bangkok: Regional Office for Asia and the Pacific of the Food and Agriculture Organization of the United Nations; 2014.

59. Ghazoul J. Mopani woodlands and the mopane worm: enhancing rural livelihoods and resource sustainability Final Technical Report. London: DFID; 2006.
60. Alltech. 2015 Global Feed Survey. 2015. http://www.alltech.com/sites/ default/files/global-feed-survey-2015.pdf Accessed 1 Oct 2015.

61. Szelei J, Woodring J, Goettel MS, Duke G, Jousset FX, Liu KY, et al. Susceptibility of North-American and European crickets to Acheta domesticus densovirus (AdDNV) and associated epizootics. J Invertebr Pathol. 2011;106(3):394-9.

62. Weissman DB, Gray DA, Pham HT, Tijssen P. Billions and billions sold: pet-feeder crickets (Orthoptera: Gryllidae), commercial cricket farms, an epizootic densovirus, and government regulations make for a potential disaster. Zootaxa. 2012;3504:67-88.

63. Stack J, Dorward A, Gondo T, Frost P, Taylor F, Kurebgaseka N. Mopane worm utilisation and rural livelihoods in Southern Africa. International Conference on Rural Livelihoods, Forests and Biodiversity; 2003 May 19-23; Bonn.

64. Kinyuru JN, Konyole SO, Onyango-Omolo SA, Kenji GM, Onyango CA, Owino VO, et al. Nutrients, functional properties, storage stability and costing of complementary foods enriched with either termites and fish or commercial micronutrients. J Insects as Food and Feed. 2015;1(2):149-58.

65. Ayieko MA, Oriamo V, Nyambuga IA. Processed products of termites and lake flies: improving entomophagy for food security within the Lake Victoria region. Afri J Food, Agric, Nutr Dev. 2010;10(2):2085-98.

66. Klunder HC, Wolkers-Rooijackers J, Korpela JM, Nout MJR. Microbiological aspects of processing and storage of edible insects. Food Control. 2012;26:628-31.

67. Belluco S, Losasso C, Maggioletti M, Alonzi CC, Paoletti MG, Ricci A. Edible Insects in a food safety and nutritional perspective: a critical review. Compr Rev Food Sci Food Saf. 2013;12(3):296-313.

68. Charlton AJ, Dickinson M, Wakefield ME, Fitches E, Kenis M, Han R, et al. Exploring the chemical safety of fly larvae as a source of protein for animal feed. J Insects Food Feed. 2015;1(1):7-16.

69. DeFoliart G. Insect as human food; Gene DeFoliart discusses some nutritional and economic aspects. Crop Prot. 1992:11:395-9.

70. Eilenberg J, Vlak JM, Nielsen-LeRoux C, Cappellozza S, Jensen AB. Diseases in insects produced for food and feed. J Insects Food Feed. 2015;1(2):87-102.

71. Verhoeckx KCM, van Broekhoven S, den Hartog-Jager CF, Gaspari M, de Jong GAH, Wichers HJ, et al. House dust mite (Der p 10) and crustacean allergic patients may react to food containing Yellow mealworm proteins. Food Chem Toxicol. 2014:65:364-73.

72. Pennisi E. All in the (bigger) family revised arthropod tree marries crustacean and insect fields. Sci Total Environ. 2015;347(6219):220-1.

73. Bequaert J. Insects as food. How they have augmented the food supply of mankind in early and recent years. Nat Hist J. 1921;21:191-200.

74. DeFoliart GR. Insects as food: why the western attitude is important Annu Rev Entomol. 1999;44:21-50.

75. Yen AL. Edible insects: traditional knowledge or western phobia? (Special Issue: Trends on the edible insects in Korea and abroad.). Entomol Res. 2009;39(5):289-98.

76. Looy H, Dunkel FV, Wood JR. How then shall we eat? Insect-eating attitudes and sustainable foodways. Agric Hum Values. 2014;31:131-41.

77. Tan HSG, Fischer ARH, Tinchan P, Stieger M, Steenbekkers LPA, van Trijp HCM. Insects as food: exploring cultural exposure and individual experience as determinants of acceptance. Food Qual Prefer. 2015;42:78-89.

78. Verbeke W. Profiling consumers who are ready to adopt insects as a meat substitute in a Western society. Food Qual Prefer. 2015;39:147-55.

79. Lensvelt EJS, Steenbekkers LPA. Exploring consumer acceptance of entomophagy: a survey and experiment in Australia and the Netherlands. Ecol Food Nutr. 2014;53(5):543-61.

80. Caparros Megido R, Sablon L, Geuens M, Brostaux Y, Alabi T, Blecker C, et al. Edible insects acceptance by Belgian consumers: promising attitude for entomophagy development. J Sens Stud. 2014;29(1):14-20.

81. Deroy $\mathrm{O}$, Reade $B$, Spence $C$. The insectivore's dilemma, and how to take the West out of it. Food Qual Prefer. 2015:44:44-55.

82. Hartmann C, Shi J, Giusto A, Siegrist M. The psychology of eating insects: A cross-cultural comparison between Germany and China. Food Qual Prefer. 2015;44:148-56

83. Van Huis A, Van Gurp H, Dicke M. The insect cookbook. New York: Columbia University Press; 2014 
84. Tranter $\mathrm{H}$. Insects creeping into English diets: introducing entomophagy to school children in a provincial town. Norwich: University of East Anglia, School of Biological Sciences; 2013.

85. Van Huis A, Vantomme P. Conference report: insects to feed the world. Food Chain. 2014;4(2):184-92.

86. Bodenheimer FS. Insects as human food; a chapter of the ecology of man. The Hague: Dr. W. Junk Publishers; 1951.

87. Lee CG, Silva CAD, Lee J-Y, Hart D, Elias JA. Chitin regulation of immune responses: an old molecule with new roles. Curr Opin Immunol. 2008;20(6):684-9.

88. Cerritos R, Cano-Santana Z. Harvesting grasshoppers Sphenarium purpurascens in Mexico for human consumption: a comparison with insecticidal control for managing pest outbreaks. Crop Prot. 2008;27(3-5):473-80.
89. De-Magistris T, Pascucci S, Mitsopoulos D. Paying to see a bug on my food: How regulations and information can hamper radical innovations in the European Union. Br Food J. 2015;117(6):1777-92.

90. Meuwissen P. Insecten als nieuwe eiwitbron - Een scenarioverkenning van de marktkansen (insects as a new protein source-an exploration of market opportunities). 's-Hertogenbosch: ZLTO projecten; 2011.

91. Lundy ME, Parrella MP. Crickets are not a free lunch: protein capture from scalable organic side-streams via high-density populations of Acheta domesticus. PLoS ONE. 2015;10(4):e0118785.

92. Drew D. Fly larvae protein, now a commercial reality for aquafeed. Aquafeed. 2015;7(1):25-8.
Submit your next manuscript to BioMed Central and take full advantage of:

- Convenient online submission

- Thorough peer review

- No space constraints or color figure charges

- Immediate publication on acceptance

- Inclusion in PubMed, CAS, Scopus and Google Scholar

- Research which is freely available for redistribution

Submit your manuscript at www.biomedcentral.com/submit 